\title{
Gossypiboma: a hidden passenger
}

\author{
John Maynard, ${ }^{1}$ Nimesh Shah, ${ }^{2}$ Katherine Groom, ${ }^{2}$ Sami Khan ${ }^{2}$
}

$1 \mathrm{UCLH}$, London, UK

${ }^{2}$ Basildon Hospital, Basildon, UK

\section{Correspondence to}

Dr John Maynard,

john.alexander.maynard@ gmail.com

Accepted 9 August 2015

\section{(DrossMark}

To cite: Maynard J, Shah $\mathrm{N}$ Groom K, et al. BMJ Case Rep Published online: [please include Day Month Year] doi:10.1136/bcr-2015212229

\section{DESCRIPTION}

We present a case of an 85-year-old man admitted with an ischaemic stroke with an incidental finding of an abdominal mass on clinical examination. CT of the abdomen revealed asymptomatic carriage of a retained surgical swab in his left lower abdomen, most likely due to an open surgical abdominal aortic aneurysm repair 8 years previously.

The barium marker embedded in cloth gives a hyperdense (metallic) coiled appearance, ${ }^{1}$ seen here with CT imaging (figures 1 and 2). This forms the core of a heterogeneous mass surrounded by a capsule, generating a radiological diagnosis of gossypiboma. The etymological basis for gossypiboma is debateable, but is likely the conjunction of 'gossypium' (Latin for 'cotton') and either the suffix 'oma' (Latin meaning 'mass') with a 'b' to separate the vowels, or 'boma' (in Swahili, 'place of concealment').

While this patient was asymptomatic, retention of such concealed foreign bodies involves potential risks to the patient in the long term. Complications include infection and abscess formation, in some cases even presenting decades after surgery. ${ }^{2}$ Other risks include adhesion formation with consequent obstruction, as well as fistula formation and migration. Furthermore, the diagnostic uncertainty posed by fragmented or degenerated materials that produce less characteristic imaging can also encourage diagnostic delay and misdiagnosis as abscesses, ${ }^{3}$ or neoplastic lesions. Given the potential for such complications, surgical removal of such materials should be strongly considered; however, in this case, this was not appropriate, given the poor physical condition of the patient at the time of writing.

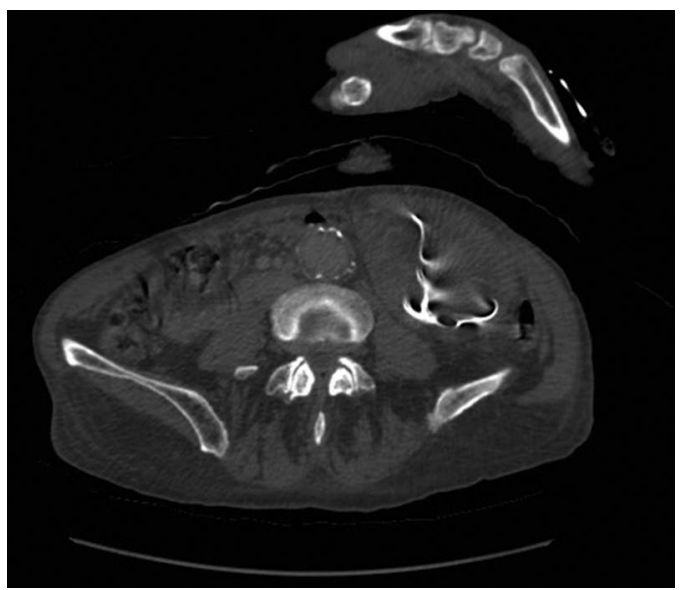

Figure 1 Left abdominal para-aortic heterogeneous mass with hyperdense core (barium impregnated threads) in axial bone and soft tissue windows.

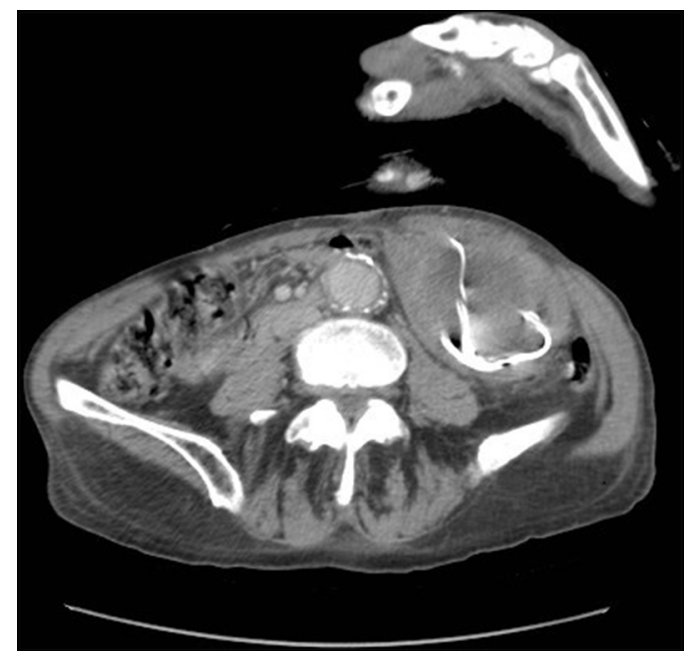

Figure 2 Left abdominal para-aortic heterogeneous mass with hyperdense core (barium impregnated threads) in axial bone and soft tissue windows.

\section{Learning points}

Surgical material counts are an essential error minimisation technique, but are not infallible.

- Retention of surgical materials may not manifest symptoms initially, and complications may present after a great delay.

- Suspicion of retention of surgical materials warrants the use of plain radiographs to detect intact radio-opaque materials in the first instance.

Contributors JM and NS contributed to the manuscript preparation; KG contributed to the manuscript preparation and patient management; SK contributed in terms of clinical advice and supervision.

Competing interests None declared.

Patient consent Obtained.

Provenance and peer review Not commissioned; externally peer reviewed.

\section{REFERENCES}

1 O'Connor AR, Coakley FV, Meng MV, et al. Imaging of retained surgical sponges in the abdomen and pelvis. Am J Roentgenolo 2003;180:481-9.

2 Ivica M, Ledinsky M, Radić B, et al. After 40 years gossypiboma caused spleen abscess. Coll Antropol 2009;33:973-5.

3 El Fortia M, Bendaoud M, Sethi S. Abdominal gossypiboma (textilioma). Internet J Radiol 2007:9. 
Copyright 2015 BMJ Publishing Group. All rights reserved. For permission to reuse any of this content visit http://group.bmj.com/group/rights-licensing/permissions.

BMJ Case Report Fellows may re-use this article for personal use and teaching without any further permission.

Become a Fellow of BMJ Case Reports today and you can:

- Submit as many cases as you like

- Enjoy fast sympathetic peer review and rapid publication of accepted articles

- Access all the published articles

- Re-use any of the published material for personal use and teaching without further permission

For information on Institutional Fellowships contact consortiasales@bmjgroup.com

Visit casereports.bmj.com for more articles like this and to become a Fellow 